\title{
On the accurate strain measurements for the crack initiation determination
}

\author{
E Mutaz The University of Queensland, Australia \\ M Serati The University of Queensland, Australia \\ DJ Williams The University of Queensland, Australia \\ VT Nguyen The University of Queensland, Australia
}

\begin{abstract}
Due to the huge demand for natural resources and minerals at a global scale, mining depths have progressively increased over the past decades to 1,000 m and deeper. However, despite many successes, deep mining operations are now facing new challenges never experienced before, including rock spalling and unwanted slabbing failures. This phenomenon is characterised as a sudden explosion-like fracture, which can affect the long-term viability and stability of deep underground mining. According to the literature, the most indicative predictor of the spalling strength at laboratory scale is the determination of the crack initiation point, which is defined as the onset of stress-induced damage in low-porosity rocks after the closure of pre-existing cracks. Hence, many methods have been developed to identify this critical design parameter, based mainly on the measurement of vertical, lateral or volumetric strains. That is, an accurate measurement of strain is deemed critical in determining the onset of the crack initiation threshold in the study of rock failure. Nevertheless, it remains difficult to determine the actual sample deformation in many geotechnical test apparatuses (i.e. multi-stage triaxial, Hoek cell, true triaxial, etc.), in which the measured deformation by linear variable differential transformers (LVDTs) is the cumulative deformation of the load frame itself, the loading platens, and the sample. As a result, relying on these deformation measurements can lead to erroneous estimation of the material's strain behaviour. This work presents a qualitative study on how to measure the actual sample deformation in a multi-functional true triaxial testing apparatus recently commissioned at the Geotechnical Engineering Centre (GEC) within the School of Civil Engineering at The University of Queensland (Brisbane, Australia).
\end{abstract}

Keywords: crack initiation threshold, spalling strength, strain measurement, true triaxial testing, strain gauges

\section{Introduction}

Unlike shallow structures in rock, deep underground spaces are generally under true polyaxial stress conditions in terms of the major $\left(\sigma_{1}\right)$, intermediate $\left(\sigma_{2}\right)$ and minor principal stresses $\left(\sigma_{3}\right)$. The redistribution of such three-dimensional (3D) complex stress states around deep excavations is deemed to be the key factor driving rock failure as the depth increases (Duan et al. 2019). Particularly in brittle and low-porosity crystalline rocks under high stresses (i.e. in hard, intact rocks in an intact state near excavation boundaries), such 3D stresses could result in a sudden and spontaneous rock collapse accompanied by a huge energy release, which is commonly known as spalling or rockburst.

Rockburst occurs violently in the form of strainburst, fault slip, or pillar burst; or in less severe ejection, which is known as spalling or slabbing failure. The first recorded rock bursting in history was in 1738 in the British tin mine in Stafford (Guo et al. 2003). In the early 1900s, this phenomenon came into sight and brought more attention (Blake \& Hedley 2003). Since then, incidents have been recorded in many places around the globe such as Sweden, Australia, Norway, Japan, USA, South Africa, Canada, China and Brazil (Martna 1972; Hargraves 1980; Selmer-Olsen 1988; Fujii et al. 1997; Whyatt et al. 2002; Brown \& Hudyma 2017; 
Wang 2018). There are over 23 countries in which the rockburst phenomenon has been observed, including France, Russia, Ukraine, and others (Zhu et al. 2019). Australia is within the top five countries in the world in the mining industry, according to Geoscience Australia, with over 350 mines operating in the country (Youwei et al. 2018). Since the early 1900s, mining-induced seismicity and related rockburst have been reported in a number of Australian mines, and particularly in recent years, these issues have become of serious concerns for the safety of versatile Australian mines and have constrained their economic viability (Potvin et al. 2000). The global mining industry market reached 800 billion dollars in 2019 (PWC Australia 2019). Therefore, solving the challenges related to this sector attracts global attention. Simulating the rock behaviour under actual true triaxial in situ conditions can expand our knowledge about rock failure and therefore facilitate the way we act to avoid such incidents.

While rockburst and spalling are commonly related to high stresses at depth in hard rock, sudden brittle failures could also happen in weaker rocks at shallow depth, in lightly cemented sandstones and in clay shales under low confinement (Kaiser \& Kim 2008); e.g. incidents have been reported at Kundana, Bounty, Mt Charlotte, Big Bell and Kanowna Belle operations at depths of 300-600 m. Nevertheless, when the mining depth approaches and exceeds $1,000 \mathrm{~m}$, the ratio of intact rock strength to the induced stresses around an excavation triggers the failure of the rock almost immediately after excavation (Kusui \& Villaescusa 2016). Similar to rockburst, spalling is closely related to the propagation and coalescence of internal tension cracks surrounding the rock (Gong et al. 2018; Bahaaddini et al. 2019). Recent research suggests that the crack initiation stress level, which is the first stage of stress-induced damage, can be used reliably as a parameter to estimate the in situ spalling strength around underground excavations in massive to moderately jointed, brittle, low-porosity rocks (Nicksiar \& Martin 2012). From this point of view, various methods have been proposed to identify the crack initiation threshold at laboratory scale. Given that most of the available methods utilise volumetric, lateral or axial strain as a benchmark to define the crack initiation point (Brace et al. 1966; Lajtai 1974; Stacey 1981; Martin \& Chandler 1994; Diederichs 2007; Nicksiar \& Martin 2012), the accurate measurement of strain in a loaded rock becomes a critical issue for the correct prediction of the in situ spalling strength.

Measuring the actual sample strain thoroughly is challenging, since most of the displacement sensors mounted on commercially available load application systems (i.e. multi-stage triaxial, Hoek cell, and true triaxial load frames) provide a combined strain measurement of the load frame itself (i.e. the metal platens) plus the rock specimen. Therefore, the strain of the metal platens should always be subtracted in the first instance using preliminary calibration charts to avoid an overestimation of the sample's true deformation (Silva et al. 2019). Alternatively, direct measurement methods through strain gauging technique can be adopted. However, given that strain gauges are relatively expensive and non-reusable, it could make the overall cost of the experimentation more expensive (Silva et al. 2019). Further, it has been shown that the direct measurement of sample deformation under three-dimensional stress conditions is extremely difficult in practice. With these motivations in mind, this study presents a systematic approach to determine the actual sample deformation under true triaxial testing conditions by subtracting the machine LVDT readings from the load cell deformation.

The true triaxial testing system designed by Mogi (1970) was the first one that enabled the application of three independent and uniform loads to rock samples (Li et al. 2012; Serati et al. 2020). Following Mogi's work, different types of true triaxial testing systems have been designed and fabricated to investigate rock behaviour under uniaxial, biaxial and true triaxial stress states (Aseyeva et al. 1987; Takahashi \& Koide 1989; Chang \& Haimson 2000; Kwasniewski et al. 2003; He et al. 2007; Ingraham et al. 2013; Kun et al. 2016). The simulation of rock behaviour in natural slopes, open pit mines, and road cuttings has been carried out successfully by adopting different stress paths in a true triaxial apparatus (Kun et al. 2016). Over 100 true triaxial testing machines (TTT) are reported in the literature to investigate the behaviour of soil, concrete, and rock under different loading conditions (Shi et al. 2012). According to Takahashi et al. (2001), TTTs can be classified based on the loading method into: type I - rigid loading in all three directions, type II - flexible loading in all three directions, and type III - a combination of both. Most of the available TTTs are of type III. Some drawbacks were detected in previous generations of TTTs, as summarised in the literature, such as 
loading eccentricity, loading gap, end friction effect and the accurate measurement of volume change (Shi et al. 2012, Feng et al. 2016).

More recently, the Geotechnical Engineering Centre (GEC) within the School of Civil Engineering at The University of Queensland in collaboration with Wille Geotechnik in Germany has designed and fabricated a state-of-the-art TTT system composed of three main units: hydraulic unit (hydraulic pack), pressure intensifiers (X, Y, Z), and loading frame (Figure 1). The system is configured to test three cubic sizes of 50, 100 and $200 \mathrm{~mm}$. The maximum applied pressure on all three orthogonal directions $(X, Y, Z)$ is $21 \mathrm{MPa}$ stress on the largest $200 \mathrm{~mm}$ cubic specimens (or up to $340 \mathrm{MPa}$ on $50 \mathrm{~mm}$ cubic samples). It is equipped with an elevated temperature facility (up to $100^{\circ} \mathrm{C}$ ), with humidity control in which a thermo-mechanical model can be developed. The system is capable of testing both saturated and unsaturated samples and is designed to accommodate the addition of monitoring equipment, including acoustic emission and ultrasonics, for the assessment of progressive damage processes (Mutaz et al. 2019). The system can also perform rock permeability testing at up to $10 \mathrm{MPa}$ pressure and hydraulic fracturing at up to $52 \mathrm{MPa}$ in three directions.

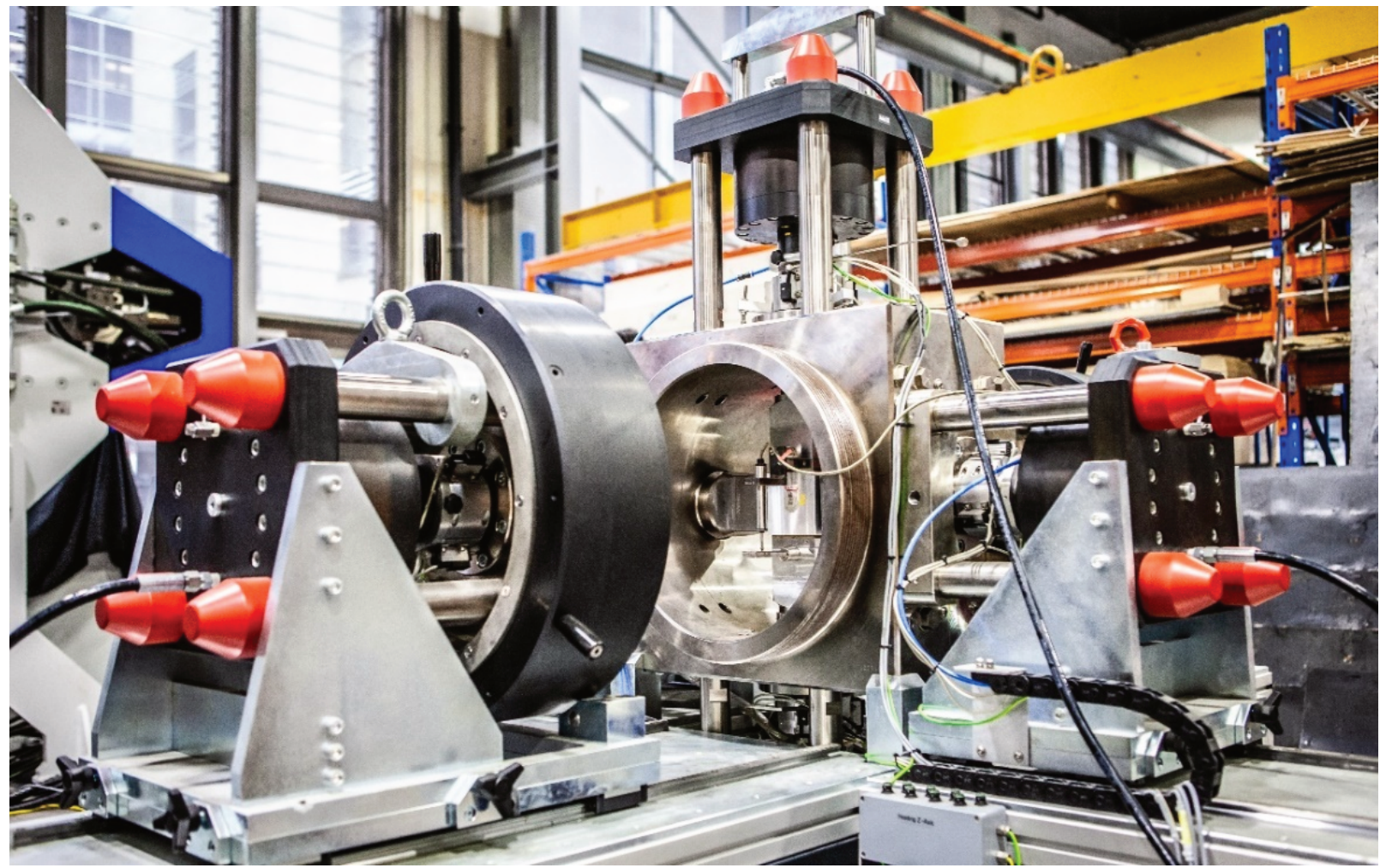

Figure 1 The University of Queensland true triaxial testing system (after Mutaz et al. 2019)

\section{$2 \quad$ Experimental testing}

\subsection{Testing plan}

In order to measure the actual sample deformation, the following equipment was used in this study:

- 10 MN Material Testing System (MTS) and 1 MN MTS compression machines.

- $100 \mathrm{~mm}$ aluminium 7075-T6 reference cube equipped with high-tech strain gauges.

- $50 \mathrm{~mm}$ reference cubes (aluminium 7075-T6, MACOR ceramic glass, stainless steel AISI 302).

- Two $100 \mathrm{~mm}$ external displacement sensors (AMETEK DFG 2.5).

- Two $50 \mathrm{~mm}$ external displacement sensors (Solartron Metrology).

- High-tech strain gauges. 
The mechanical properties of the standard cubes are given in Table 1, while the high-tech strain gauge characteristics are given in Table 2 . The calibration curves of both external displacement sensors are shown in Figure 2. The following steps were adopted in order to measure the cell deformation and hence the actual deformation of the sample:

- Attaching the high-tech strain gauges to the standard cubes to measure their deformation at the centre by assuming the cubes will deform similarly at the mid, top and bottom points.

- Testing the standard cubes using an MTS loading frame under different loading conditions and measuring the central sample deformation via strain gauges and the overall sample deformation through external displacement sensors fixed across the sample.

- Testing the standard cubes using the TTT system under the same loading conditions as the MTS loading frame and measuring the central sample deformation using the strain gauges, while the overall displacements were measured using the mounted LVDTs of the true triaxial.

- The strain measurement of the strain gauges was used to measure the material's elastic parameters; elastic modulus and Poisson's ratio.

- Comparing the results of the strain gauges in both loading frames under the same loading conditions to indicate the accuracy of the force measurement in the newly developed TTT system.

- Consequently, the TTT deformation was calculated by subtracting the readings of the external displacement sensors on the MTS loading frame from the true triaxial LVDT readings.

Table 1 Mechanical properties of the standard cubes

\begin{tabular}{lll}
\hline Cube type & Elastic modulus (E) (GPa) & Poisson's ratio (v) \\
\hline Aluminium (7075-T6) & 71.7 & 0.33 \\
MACOR ceramic glass & 66.9 & 0.29 \\
Stainless steel AISI 302 & 180 & 0.29 \\
\hline
\end{tabular}

Table 2 Strain gauge characteristics

\begin{tabular}{ll}
\hline Design parameter & Reference datasheet \\
\hline Strain gauges type & FCAB-5-8 \\
Adhesive type & $\mathrm{P}-2$ \\
Coefficient of thermal expansion & $8.1 \times 10^{-6} /{ }^{\circ} \mathrm{C}$ \\
Temperature coefficient & $+0.1 \pm 0.05 \% / 10^{\circ} \mathrm{C}$ \\
Tolerance & $\pm 0.85\left[(\mu \mathrm{m} / \mathrm{m}) /{ }^{\circ} \mathrm{C}\right]$ \\
\hline
\end{tabular}




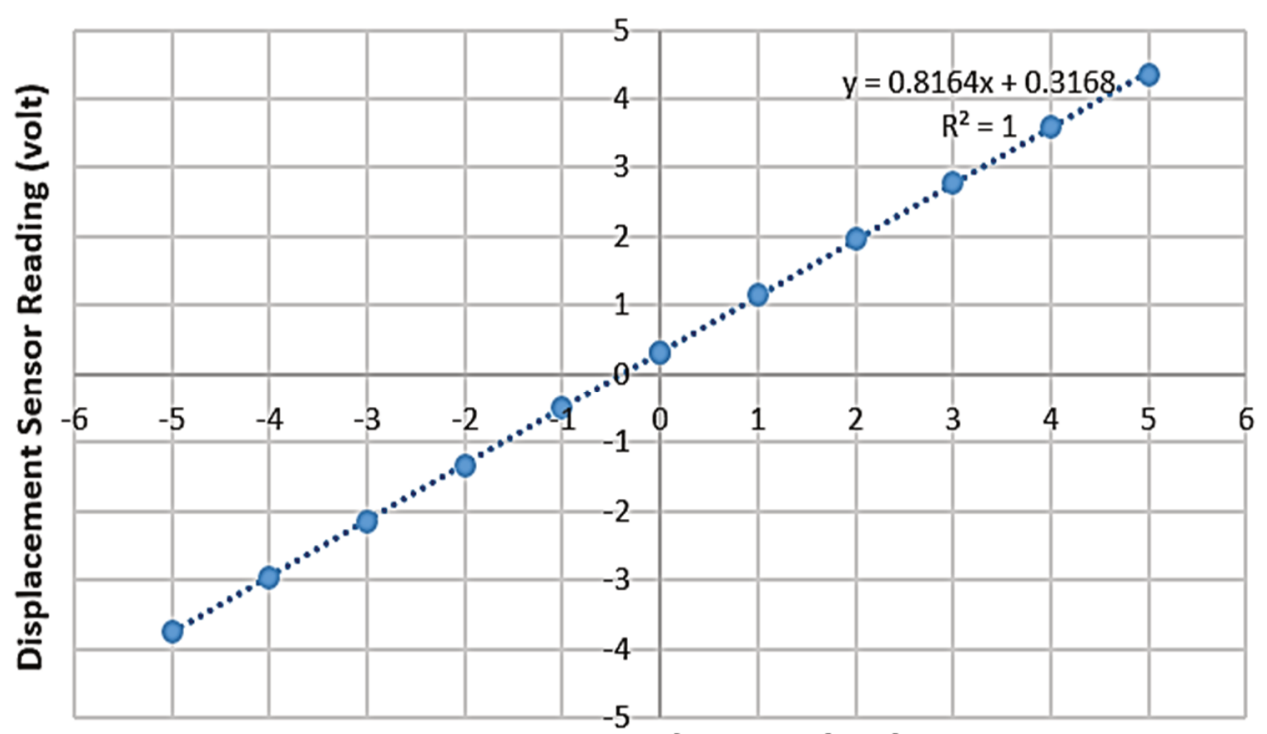

Micrometer Displacement (mm)

(a)

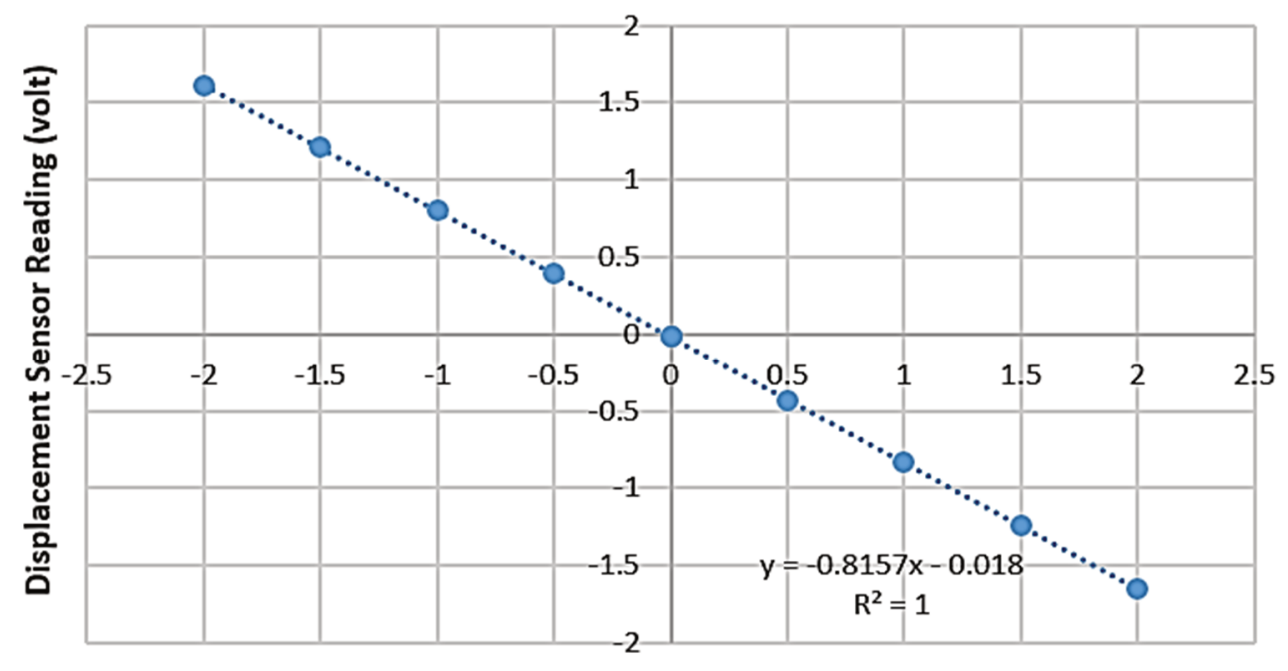

Micrometer Displacement (mm)

(b)

Figure 2 Calibration curves of the external displacement sensors: (a) $100 \mathrm{~mm}$ AMETEK DFG 2.5; (b) $50 \mathrm{~mm}$ Solartron Metrology

\subsection{Elastic parameter measurement}

All strain gauges were glued at the centre of the sample and the strain signals were recorded by NI 9236 and NI 9235 modules. The analogue outputs of the external displacement sensors were recorded by a module NI 9215 with 16-bit resolution, resulting in $0.37 \mu \mathrm{m}$ displacement resolution. To ensure proper contact between the cubes and the loading platens, a constant seating pressure was maintained before each test; i.e. $7-12 \%$ of the maximum applied load. Table 3 presents the designated loading condition throughout the whole process. The configuration of the samples inside the TTT and the MTS loading frames is shown in Figures 3 and 4; respectively. 
Table 3 Designated loading condition

\begin{tabular}{lllll}
\hline Cube type & $\begin{array}{l}\text { Cube size } \\
(\mathbf{m m})\end{array}$ & $\begin{array}{l}\text { Loading rates } \\
(\mathrm{kN} / \mathrm{min})\end{array}$ & $\begin{array}{l}\text { Maximum } \\
\text { load }(\mathrm{kN})\end{array}$ & $\begin{array}{l}\text { Maximum } \\
\text { pressure (MPa) }\end{array}$ \\
\hline Aluminium & $100 \times 100$ & $\begin{array}{l}50,100,200,300, \\
400,500,600\end{array}$ & 666 & 66 \\
Aluminium & & & & \\
Ceramic & $50 \times 50$ & $\begin{array}{l}50,100,200,300, \\
400\end{array}$ & 400 & 160 \\
Steel & & & \\
\hline
\end{tabular}

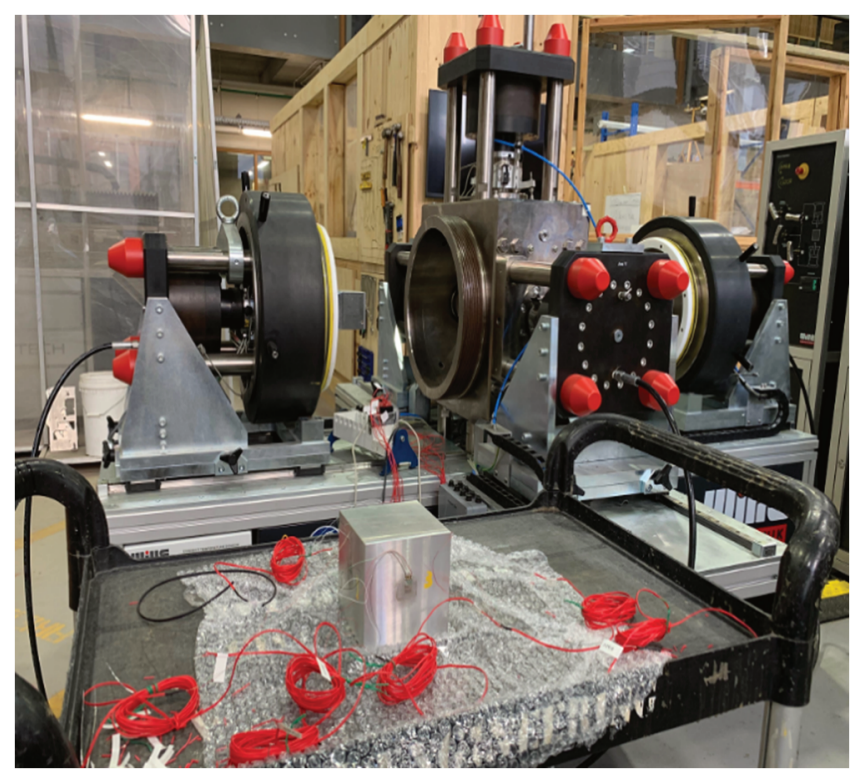

(a)

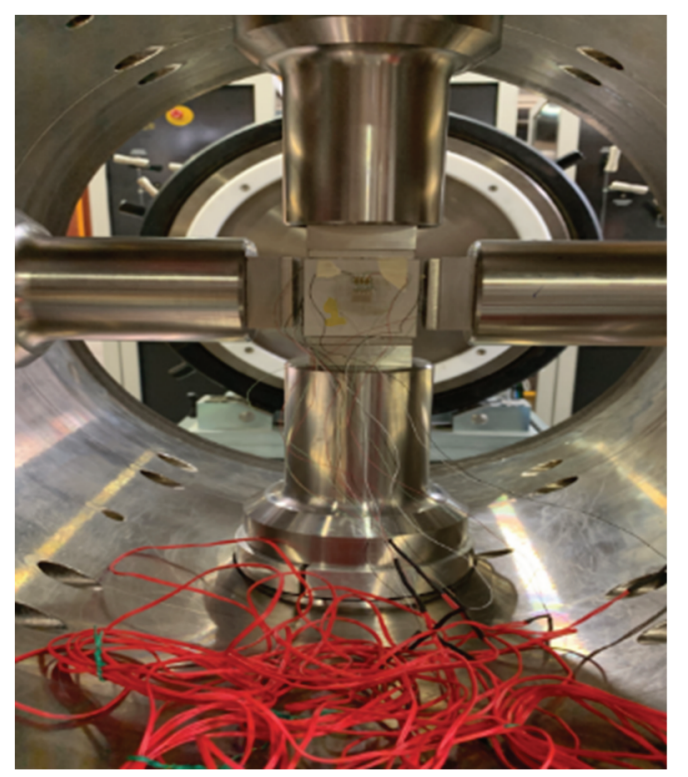

(b)

Figure 3 Sample positioned inside the true triaxial loading cell for: (a) $100 \mathrm{~mm}$ cube (after Mutaz et al. 2019); (b) $50 \mathrm{~mm}$ cube

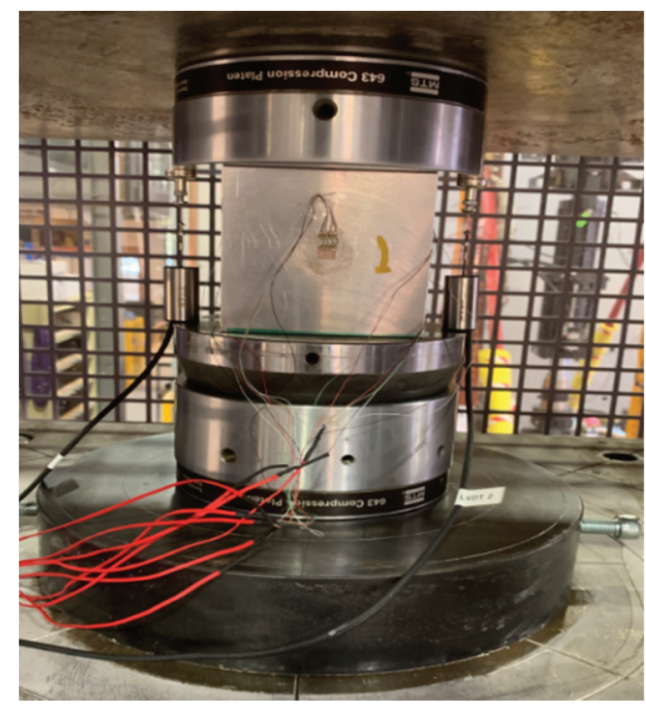

(a)

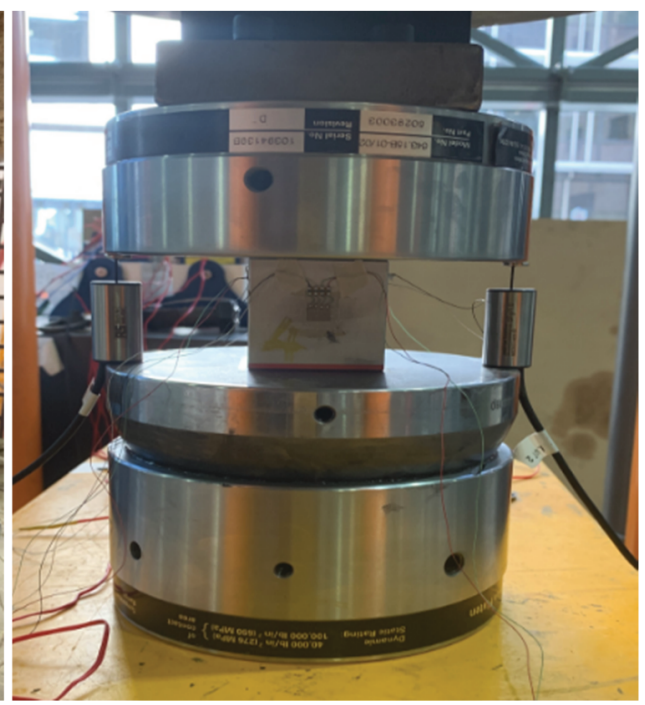

(b)

Figure 4 The external displacement sensors positioned inside: (a) $10 \mathrm{MN}$ MTS for $100 \mathrm{~mm}$ cube (after Mutaz et al. 2019); (b) 1 MN MTS for $50 \mathrm{~mm}$ cube 
Under the same loading conditions, but different loading rates, the variation of strain gauge readings between the MTS loading frame and the TTT system was very small (less than $0.003 \mathrm{~mm}$ or a strain value of $0.00003 \%$ ) for the tested cubes. Figures 5 and 6 present the relative difference between the strain gauge reading in the MTS and TTT systems for 100 and $50 \mathrm{~mm}$ aluminium cubes, respectively, under different loading and loading rates. This finding provides evidence of the accuracy of the loading measurement in the TTT system.

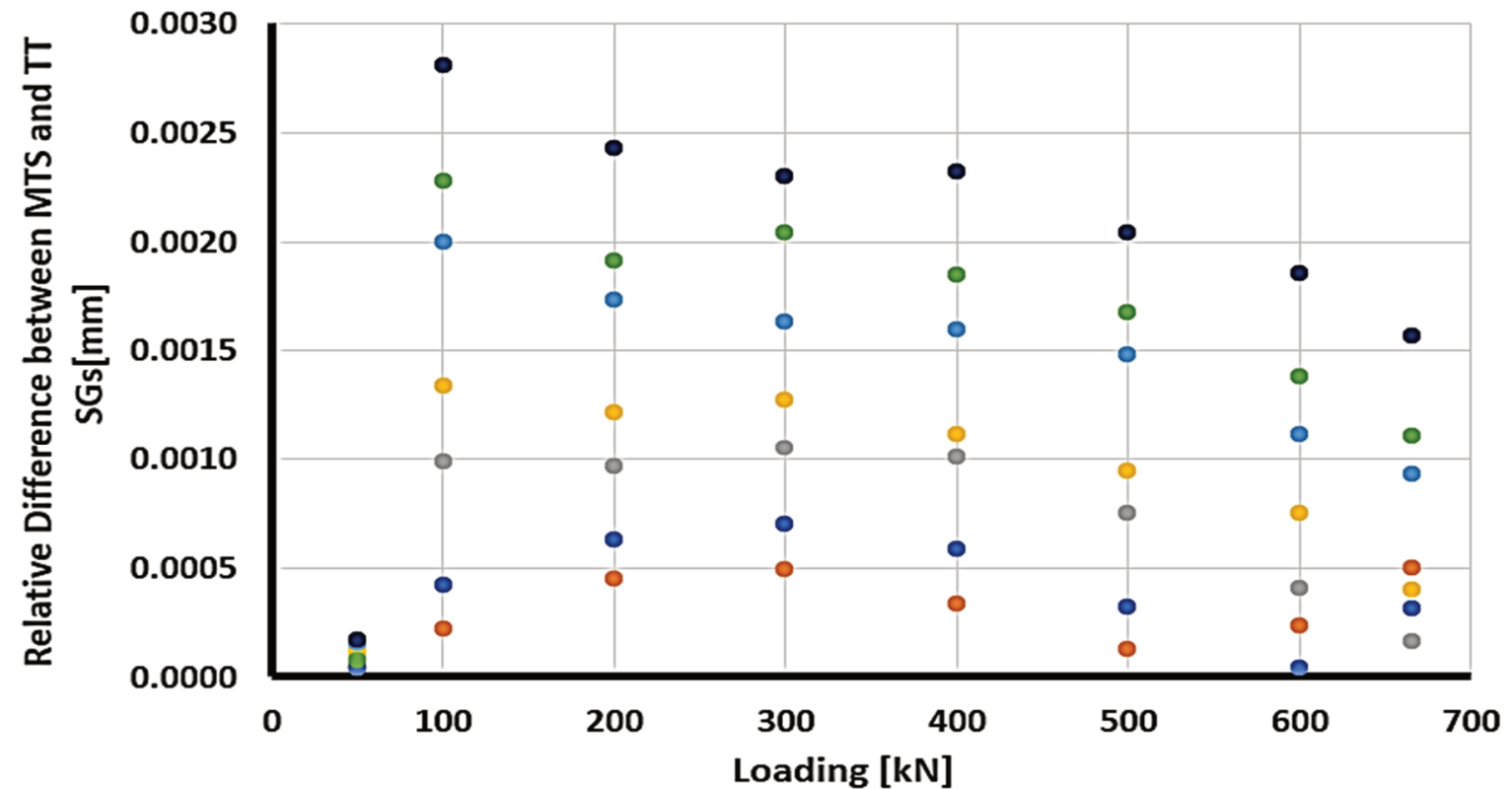

- Loading Rate $=50 \mathrm{kN} / \mathrm{min} \bullet$ Loading Rate $=100 \mathrm{kN} / \mathrm{min} \bullet$ Loading Rate $=200 \mathrm{kN} / \mathrm{min}$ Loading Rate $=300 \mathrm{kN} / \mathrm{min}$ - Loading Rate $=400 \mathrm{kN} / \mathrm{min} \bullet$ Loading Rate $=500 \mathrm{kN} / \mathrm{min} \bullet$ Loading Rate $=600 \mathrm{kN} / \mathrm{min}$

Figure 5 Relative difference of strain gauge readings between MTS and true triaxial for $100 \mathrm{~mm}$ aluminium cube

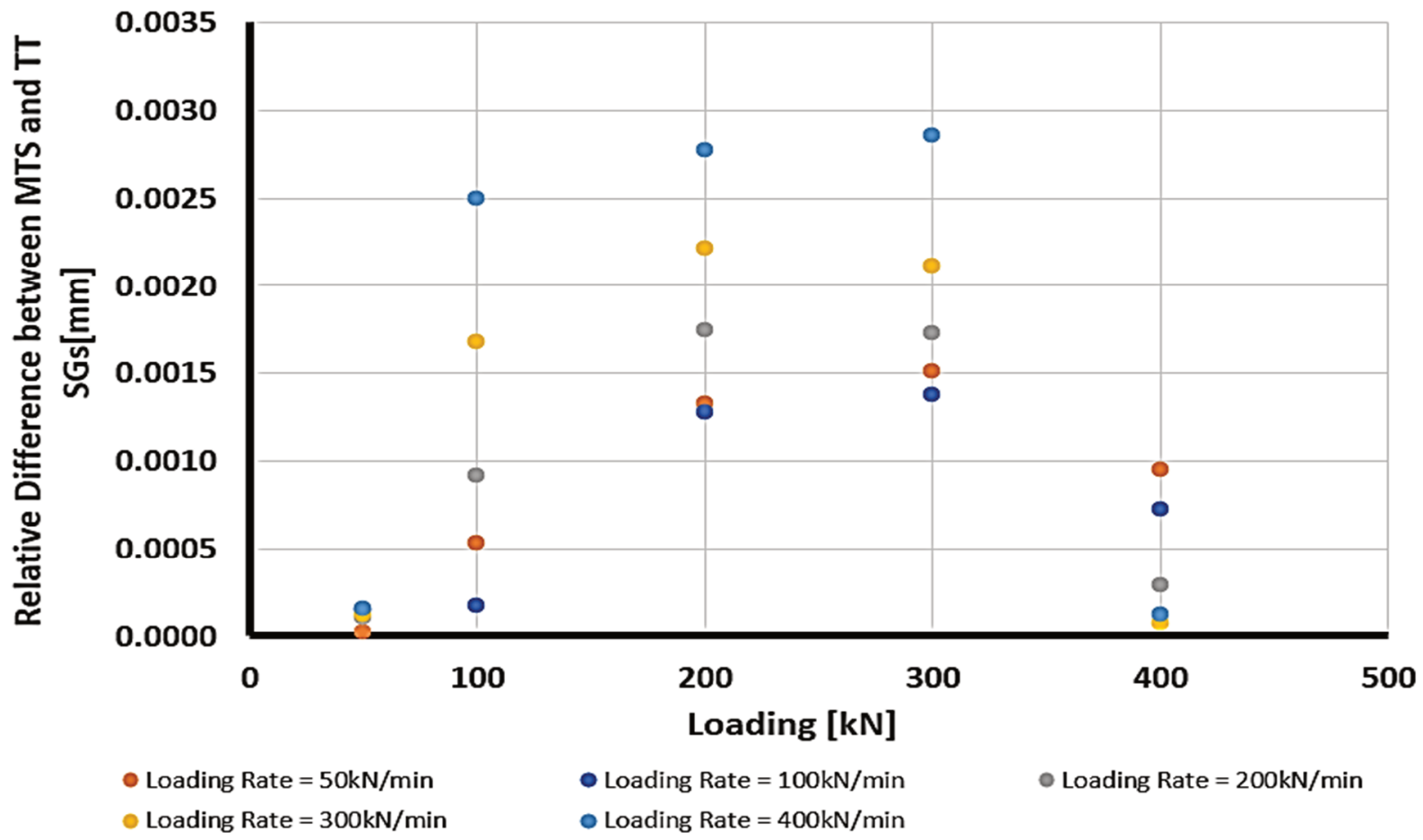

Figure 6 Relative difference of strain gauge readings between MTS and true triaxial for $50 \mathrm{~mm}$ aluminium cube 
Martin \& Chandler (1994) proposed that the crack threshold stress can also be calculated by measuring the so-called crack volumetric strain $(\Delta \mathrm{V} / \mathrm{V})_{\mathrm{cr}}$, which is defined by subtracting the elastic volumetric strain $(\Delta \mathrm{V} / \mathrm{V})_{\mathrm{el}}$ from the total volumetric strains $(\Delta \mathrm{V} / \mathrm{V})$ in a triaxial testing condition, or:

$$
\left(\frac{\Delta V}{V}\right)_{c r}=\left(\frac{\Delta V}{V}\right)_{\text {total }}-\left(\frac{\Delta V}{V}\right)_{e l}
$$

It can readily be shown that the value of elastic volumetric strain is related to the material's Young's modulus and Poisson's ratio according to:

$$
\left(\frac{\Delta V}{V}\right)_{e l}=\frac{2 v-1}{E}\left(\sigma_{1}+2 \sigma_{3}\right)
$$

That is, the accurate determination of Young's modulus (elastic modulus) and Poisson's ratio could also have a great impact on the measurement of the crack initiation point. The variation of the elastic modulus for different material types under different loading conditions is presented in Figure 7. The relative error in measuring the elastic modulus by using the TTT is in the range of $5.0-9.0 \%$ for aluminium, ceramic and steel cubes. The logic behind this relatively low error is that the measurement of strain has been considered at the centre of the sample using the centrally located strain gauges.

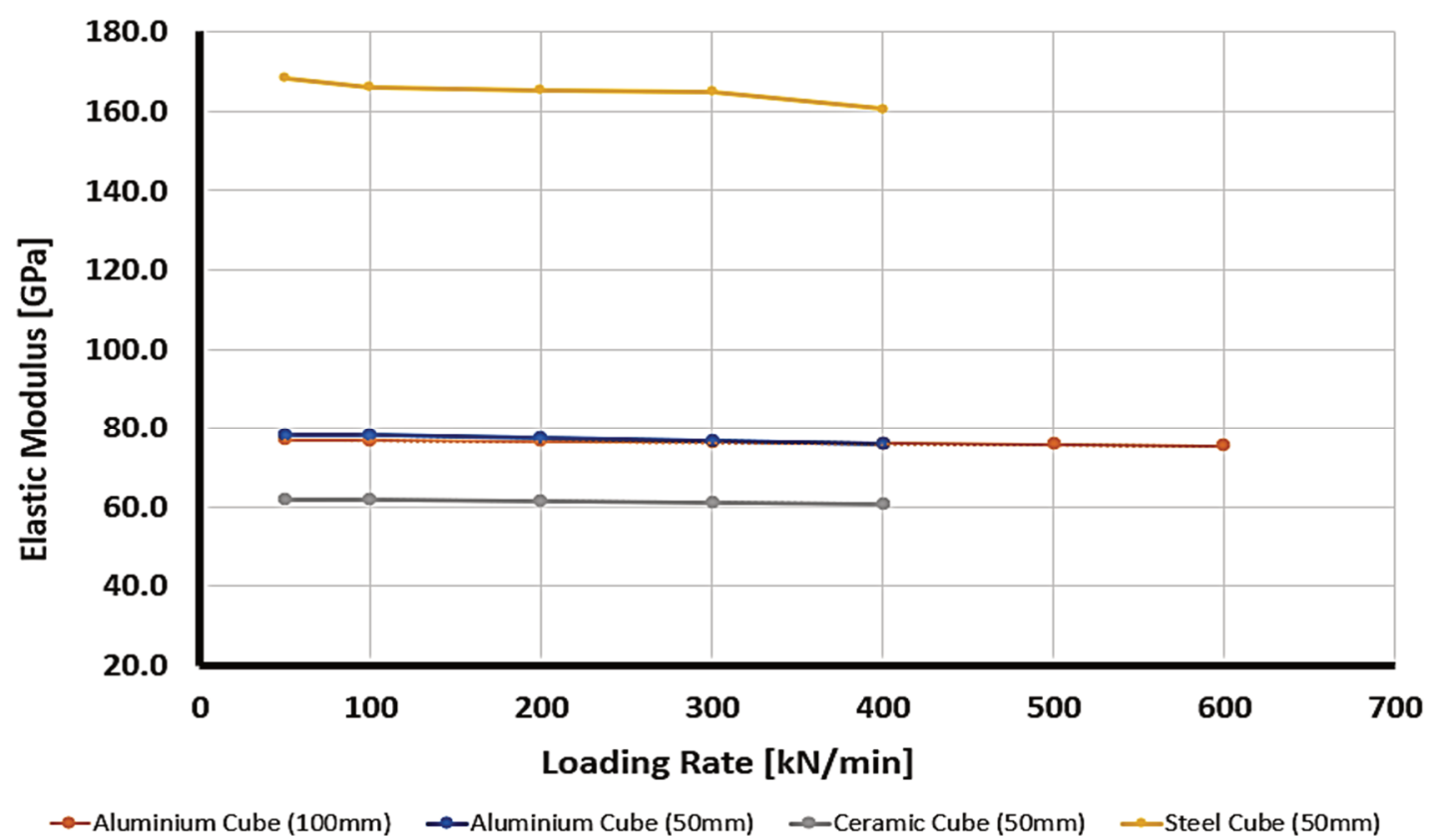

Figure 7 Variation of measured elastic modulus through true triaxial at different loading rates

\subsection{Cell deformation}

The main aim of this study is to measure the cell deformation, which is equivalent to the overall displacement of the loading cell and loading platens. Since the LVDTs of the TTT are mounted on the ram piston, they measure the overall deformation of the cell plus the actual sample deformation. The external displacement sensors that are attached along the cubes in the MTS loading frame (Figure 4) were used to determine the actual sample deformation across its full length. Therefore, the cell deformation can be calculated by subtracting the displacement of the true triaxial LVDTs that are mounted on the true triaxial ram piston from the displacement of the external displacement sensors on the MTS loading frame, to give:

$$
D_{\text {cell }}=D_{T T L V D T}-D_{M T S D S}
$$

where:

$D_{T T L V D T}=$ the true triaxial LVDT readings.
$D_{M T S D S}=$ the displacement readings from the external displacement sensors of the MTS. 
The cell deformation has been calculated for all the three reference cubes (aluminium, ceramic and steel) as illustrated in Figure 8. It can be deduced that the cell deformation is an intrinsic property of the cell material itself and is solely a function of the applied load. In other words, the cell deformation (on each axis) is independent of the rock/sample being tested inside the loading frame and is only a function of the material of the loading frame and the applied stress level (Figure 8).

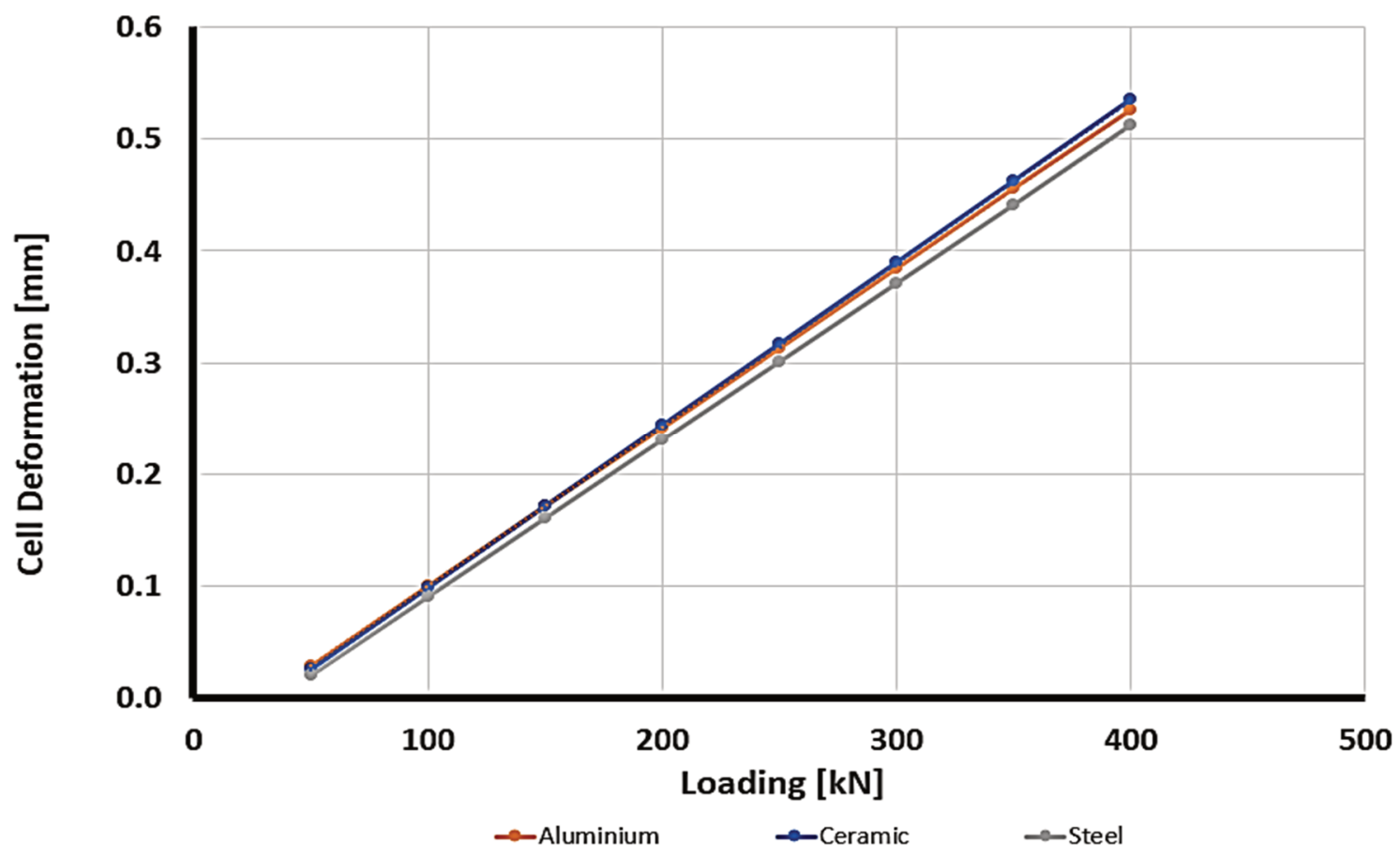

Figure 8 True triaxial cell deformation for aluminium, ceramic and steel, on the $Z$ axis

However, in a TTT system, different components of the machine transfer the load onto the sample in each axis. Therefore, it is important to measure the cell deformation in all directions (major, intermediate and minor principal stresses). The cell deformation was calculated for each axis ( $\mathrm{X}, \mathrm{Y}$ and $\mathrm{Z}$ ) using the $50 \mathrm{~mm}$ aluminium reference cube (Figure 9). Table 4 summarises the cell deformation equations in all three axes. The load cell deformation in all three axes is not the same, but can be given as a function of the applied load as given in Table 4.

Table 4 Cell deformation equations in all three axes for $50 \mathrm{~mm}$ standard aluminium cube

\begin{tabular}{lll}
\hline $\mathbf{Z}$ axis & $\mathbf{Y}$ axis & $\mathbf{X}$ axis \\
\hline$y=0.0016 x-0.0751$ & $y=0.0014 x-0.0756$ & $y=0.0013 x-0.067$ \\
\hline
\end{tabular}




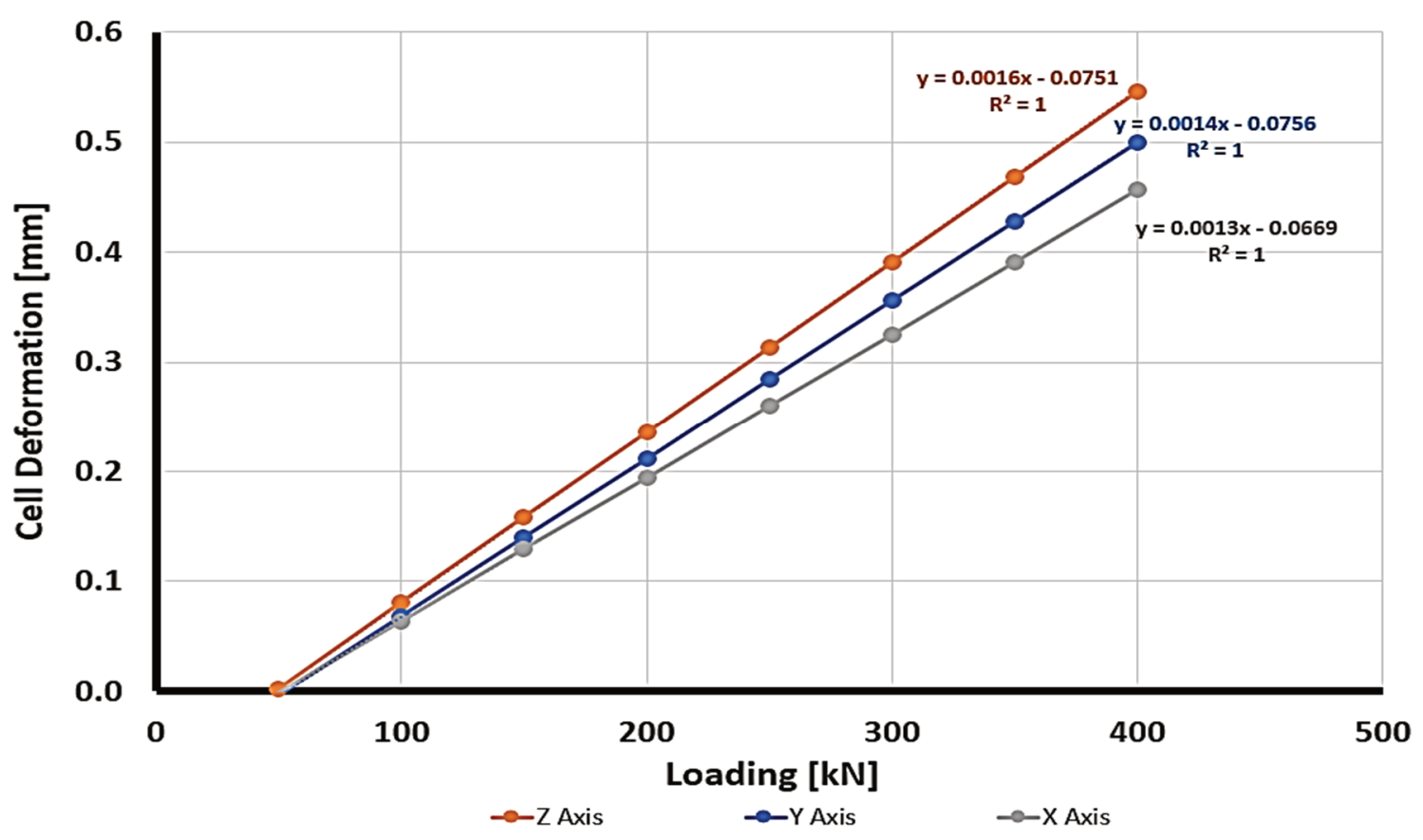

Figure 9 Cell deformation of true triaxial for $50 \mathrm{~mm}$ aluminium cube in all three stress directions

\section{Conclusion}

The increasing depth of mining is associated with many problems, such as underground rock spalling and rockburst. A proper prediction of the in situ spalling strength plays a vital role in preventing catastrophic damage to deep underground mines. True triaxial testing systems have been used widely to characterise, model and predict the in situ spalling strength. Recent research shows that spalling failure is likely to occur when the induced stresses trigger the onset of cracks. The literature is replete with many models to predict crack initiation based on stress-strain response. However, most of the displacement sensors that are mounted on TTT machines measure the overall displacement of the loading cell plus the actual sample deformation. Dismissing the actual sample deformation and relying only on the loading frame displacement can result in an inaccurate measurement of the material's strain and hence affect the accurate prediction of the in situ spalling strength. This work was aimed at assessing a testing procedure to measure the actual sample deformation without the need for further strain gauging.

\section{References}

Aseyeva, T, Alexeev, A, Viktorov, V \& Stratikov, G 1987, 'A plant for three-axis compression tests of prismatic specimens', U.S.S.R. Patent No. 1285340, Priority 1984 (in Russian).

Bahaaddini, M, Serati, M, Masoumi, H \& Rahimi, E 2019, 'Numerical assessment of rupture mechanisms in Brazilian test of brittle materials', International Journal of Solids and Structures, vol. 180-181, pp. 1-12.

Blake, W \& Hedley, DG 2003, Rockbursts, Case Studies from North American Hard-Rock Mines, Society for Mining, Metallurgy and Exploration Inc., Englewood.

Brace, WF, Paulding, B \& Scholz, C 1966, 'Dilatancy in the fracture of crystalline rocks', Journal of Geophysical Research, vol. 71, pp. 3939-3953.

Brown, L \& Hudyma, M 2017, Canadian Seismicity and Rockburst Database, technical report, January 2017.

Chang, C \& Haimson, B 2000, 'True triaxial strength and deformability of the German Continental Deep Drilling Program (KTB) deep hole amphibolite', Journal of Geophysical Research, vol. 105, pp. 18999-19013.

Diederichs, MS 2007, 'The 2003 Canadian Geotechnical Colloquium: mechanistic interpretation and practical application of damage and spalling prediction criteria for deep tunnelling', Canadian Geotechnical Journal, vol. 44, pp. 1082-1116.

Duan, G, Li, J, Zhang, J, Assefa, E \& Sun, X 2019, 'Mechanical properties and failure modes of rock specimens with specific joint geometries in triaxial unloading compressive test', Advances in Materials Science and Engineering, vol. 2019, https://doi.org/10.1155/2019/1340934

Feng, X-T, Zhang, X, Kong, R \& Wang, G 2016, 'A novel Mogi type true triaxial testing apparatus and its use to obtain complete stress-strain curves of hard rocks', Rock Mechanics and Rock Engineering, vol. 49, pp. 1649-1662. 
Fujii, Y, Ishijima, Y \& Deguchi, G 1997, 'Prediction of coal face rockbursts and microseismicity in deep longwall coal mining', International Journal of Rock Mechanics and Mining Sciences, vol. 34, no. 01, pp. 85-96.

Gong, F, Luo, Y, Li, X-B, Si, X-F \& Tao, M 2018, 'Experimental simulation investigation on rockburst induced by spalling failure in deep circular tunnels', Tunnelling and Underground Space Technology, vol. 81, pp 413-427.

Guo, R, Pan, CL \& Yu, RC 2003, Theory and Technique of Mining Dealing with Hard Rock Deposits Liable to Rockburst, Metallurgical Industry Press, Beijing.

Hargraves, AJ 1980, 'Keynote address - a review of instantaneous outburst data', Symposium on the Occurrence Prediction and Control of Outbursts in Coal Mines Symposium, The Australian Institute of Mining and Metallurgy, Melbourne, pp. 1-18.

$\mathrm{He}, \mathrm{M}$, Miao, J \& Li, D 2007, 'Experimental study on rockburst processes of granite specimen at great depth', Chinese Journal of Rock Mechanics and Engineering, vol. 26, no. 5, pp. 865-876 (in Chinese).

Ingraham, M, Issen, K \& Holcomb, D 2013, 'Response of Castlegate sandstone to true triaxial states of stress', Journal of Geophysical Research, vol. 118, pp. 536-552.

Kaiser, PK \& Kim, B-H 2008, 'Rock mechanics challenges in underground construction and mining', in Y Potvin, J Carter, A Dyskin \& R Jeffrey (eds), Proceedings of the First Southern Hemisphere International Rock Mechanics Symposium, Australian Centre for Geomechanics, Perth, pp. 23-38, https://doi.org/10.36487/ACG_repo/808_83

Kun, D, Ming, T, Li, X-B \& Jian, Z 2016, 'Experimental study of slabbing and rockburst induced by true-triaxial unloading and local dynamic disturbance', Rock Mechanics and Rock Engineering, vol. 49, pp. 3437-3453.

Kusui, A \& Villaescusa, E 2016, 'Seismic response prior to spalling failure in highly stressed underground tunnels', Proceedings of the Seventh International Conference \& Exhibition on Mass Mining (MassMin 2016), Australasian Institute of Mining and Metallurgy, Melbourne.

Kwasniewski, M, Takahashi, M \& Li, X 2003, 'Volume changes in sandstone under true triaxial compression conditions', Proceedings of the 10th ISRM Congress International Society for Rock Mechanics, South African Institute of Mining and Metallurgy, Johannesburg, pp. 683-688.

Lajtai, EZ 1974, 'Brittle fracture in compression', International Journal of Fracture Mechanics, vol. 10, pp. 525-536.

Li, X, Shi, L, Bai, B, Li, Q \& Xu, D 2012, 'True-triaxial testing techniques of rocks - state of the art and future perspectives', in M Kwaśniewski, X Li \& M Takahashi (eds), True Triaxial Testing of Rocks, CRC Press, Boca Raton, pp. 3-18.

Martin, CD \& Chandler, NA 1994, 'The progressive fracture of Lac du Bonnet granite', International Journal of Rock Mechanics and Mining Sciences \& Geomechanics Abstracts, vol. 31, no. 6, pp.643-659.

Martna, J 1972, 'Selective overbreake in the Suorva-Vietas tunnel caused by rock pressure', Proceeding of the International Symposium on Underground Openings, Swiss Society for Soil Mechanics and Foundation Engineering, Zürich, pp. 141-145.

Mogi, K 1970, 'Effect of the triaxial stress system on rock failure', Rock Mechanics In Japan, vol. 1, pp. 53-55.

Mutaz, E, Serati, M, Nguyen, VT \& Williams, DJ 2019, 'Effects of testing conditions on measurement of material's elastic properties', Proceedings of the ISRM2019 Specialized Conference, International Society for Rock Mechanics and Rock Engineering, Lisbon.

Nicksiar, M \& Martin, CD 2012, 'Evaluation of methods for determining crack initiation in compression tests on low-porosity rocks', Rock Mechanics and Rock Engineering, vol. 45, pp. 607-617.

Potvin, Y, Hudyma, M \& Jewell, R 2000, 'Rockburst and seismic activity in underground Australian mines - an introduction to a new research project', ISRM International Symposium, International Society for Rock Mechanics and Rock Engineering, Lisbon.

PwC Australia, Mine 2019: Resourcing the Future, https://www.pwc.com.au/mining/global-mine-2019.html

Selmer-Olsen, R 1988, 'General engineering design procedures', Norwegian Tunneling Today, pp. 53-58.

Serati, M , Mutaz , E, Williams, DJ, Quintero OS, Karlovsek, J \& Hanzic, L 2020, 'Failure mode of concrete under polyaxial stresses', Proceedings of the 54th US Rock Mechanics/Geomechanics Symposium, American Rock Mechanics Association, Alexandria.

Shi, L, Li, X, Bai, B, Li, Q \& Feng, X 2012, 'Numerical analysis of loading boundary effects in Mogi-type true triaxial tests', in M Kwasniewski, X Li \& M Takahashi (eds), True Triaxial Testing of Rocks, CRC Press, Boca Raton, pp. 19-33.

Silva, AL, Varanis, M, Mereles, AG, Oliveira, C \& Balthazar, JM 2019, 'Study of strain and deformation measurement using the Arduino microcontroller and strain gauges devices', Revista Brasileira de Ensino de Física, vol. 41.

Stacey, TR 1981, 'A simple extension strain criterion for fracture of brittle rock', International Journal of Rock Mechanics and Mining Sciences \& Geomechanics Abstracts, vol. 18, pp. 469-474.

Takahashi, M \& Koide, H 1989, 'Effect of the intermediate principal stress on strength and deformation behaviour of sedimentary rocks at the depth shallower than 2000 m', in V Maury \& D Fourmaintraux (eds), Rock at Great Depth, vol 1, A.A. Balkema, Rotterdam, pp. 19-26

Takahashi, M, Narite, T \& Tomishima, Y 2001, 'Various loading systems for rock true triaxial compression test', Journal of the Japan Society of Engineering Geology, vol. 42, no. 4, pp. 242-247 (in Japanese).

Wang, C 2018, Evolution, Monitoring and Predicting Models of Rockburst - Precursor Information for Rock Failure, Springer, Singapore, https://doi.org/10.1007/978-981-10-7548-3

Whyatt, JK, Blake, W, Williams, TJ \& White, BG 2002, 'Mining publication: 60 years of rockbursting in the Coeur D'Alene district of northern Idaho, USA: lessons learned and remaining issues', Proceedings of the 109th Annual Exhibit and Meeting, Society for Mining, Metallurgy, and Exploration, Englewood.

Youwei, X, Shengshen, WU, Williams, DJ \& Serati, M 2018, 'Determination of peak and ultimate shear strength parameters of compacted clay', Engineering Geology, vol. 243, pp. 160-167, https://doi.org/10.1016/j.enggeo.2018.07.001

Zhu, X, Jin, X, Jia, D, Sun, N \& Wang, Pu 2019, 'Application of data mining in an intelligent early warning system for rock bursts', Processes 2019, vol. 7, no. 55. 
